\title{
Study of the Environmental Effects on Holstein Cows' Milk Performance under Tunisian Conditions
}

\author{
S. Bedhiaf-Romdhani ${ }^{1, *}$, M. Djemali ${ }^{2}$ \\ ${ }^{1}$ INRA-TUNISIA, Laboratory of Animal and Fodder Productions, Rue Hédi Karray, 1004 El Menzah, Tunisia \\ ${ }^{2}$ INAT-TUNISIA, Laboratory of Animal and Food Resources, 1082 City Mahrajène, Tunisia
}

Copyright $(2017$ by authors, all rights reserved. Authors agree that this article remains permanently open access under the terms of the Creative Commons Attribution License 4.0 International License

\begin{abstract}
Analyses of milk data of 74201 lactations from 327 Friesian dairy herds recorded during 1998-2009 and a total of 25,000 lactations from 156 Friesian dairy herds recorded during 1983-1987 under south Mediterranean environmental production conditions identified significant sources of variation by region, herd-year within region countries of origin, month of calving and days in milk for dairy cattle milk yield. The specific objective of this study was to quantify the effect of climate change by examining the effect of month of calving on milk yield of Friesian dairy cattle during two periods (1983-1987) and (1998-2009). In the first period, cows were North American Holsteins (2\%), European Friesian (28\%) and their progeny born and raised in Tunisia $(70 \%)$. In the second period North American sired cows were (19\%) and European sired cows were (14\%). The effect of month of calving on milk yield was quantified by the least squares solutions obtained with the last month restricted to zero. In both periods, cows calving in the fall and early winter (September-January) yielded more milk than cows calving in spring (February-May) or summer (June-August). In the first period, cows calving in January yielded $384 \mathrm{~kg}$ more milk than cows calving in August. In the second period, the difference of milk yield between January and August was reduced to be only $220 \mathrm{~kg}$. In the first period (1983-1987), least square means differences of milk yield from January to December (as a basis of comparison) were respectively, $(113 \mathrm{~kg},-34 \mathrm{~kg},-76 \mathrm{~kg}$, $-100 \mathrm{~kg},-189 \mathrm{~kg},-238 \mathrm{~kg},-246 \mathrm{~kg},-271 \mathrm{~kg},-160 \mathrm{~kg}, 7 \mathrm{~kg}, 35 \mathrm{~kg}$, $0)$. These differences were, respectively, in the second period $(-47 \mathrm{~kg}, 6 \mathrm{~kg},-30 \mathrm{~kg},-86 \mathrm{~kg},-203 \mathrm{~kg},-226 \mathrm{~kg},-267 \mathrm{~kg},-268 \mathrm{~kg}$, $-177 \mathrm{~kg},-76 \mathrm{~kg},-47 \mathrm{~kg}, 0)$. In the second period $(1998-2009)$ and in relation to calving months, there is a clean tendency of a decrease in differences of total milk produced, between what is known in the first period (1983-1987) as traditional cool months and hot months which might be a climate change translation. This study showed how calving month effect on milk yield could be used over time as a measured indicator of climate changes.
\end{abstract}

Keywords Climate, Change, Friesians, Calving, Mediterranean

\section{Introduction}

Since domestication took place, animal genetic resources have played key roles in providing food to a growing human population in different environments ranging from favorable to harsh producing conditions. The effects of global warming on agriculture in general and livestock in particular and the increasing food prices are putting pressure nationally and internationally on all types of production systems. Producers are facing, under these prevailing conditions, a double of challenge of dealing with the impact of climate change at the same time that they must increase production to meet a massive demand of a global population projected to reach more than 9 billion by 2050 (FAO, 2011).

Exploring technological, policy, strategic and social responses pathways to climate change is becoming, today, a priority in the framework of food security worldwide. Many indicators of climate change relied on temperature trends. The effect of temperature on animal performances during time could be considered, in this regard, a valuable quantitative biological indicator of climate change measurement. Many studies showed that calving month effect is a significant source of variation on cows' performances in different regions in the world. In United Kingdom, Amies (1981) and Poole (1988) reported large differences in total milk between cows calving in different months of the year. Annis et al. (1959) reported differences between the calving month in the milk yield and milk fat in three different dairy breeds in USA. Raysildo et al.(1980) reported the effect of season of calving on lactation length and milk yield under tropical environmental conditions. In South Africa, Mostert et al.(2001) reported that cows calving in mid-winter (June-July) yielded more milk than those calving in mid-summer (December-January) and Djemali and Berger (1992) reported, under North African environmental conditions, that cows calving in the fall and early winter (September-January) yielded more milk than 
cows calving in spring or summer (July-August). Therefore, databases of milk recording in various geographic regions in the world could be used to assess climate changes based on the effect of month or year of calving on animals' performances. Cows are affected by cold winter temperatures and hot summer temperatures and the effect of these temperatures are translated into milk yield and reproductive performances constituting, consequently, measurable indicators of the effect of climate temperatures during time. The effect of month or season of calving on herd performance should not be considered only as a problem associated with countries that have either lower winter or higher summer temperatures, but if information gathered during longer periods permit, as an indicator to climate change as well. The main objective of this study was to show how the effect of month of calving on milk yield of dairy cattle can be used as an indicator to climate change assessment.

\section{Material and Methods}

The data were 74201 complete lactation records from 327 herds under the official (A4) national milk recording system since the early 1960s. The data was provided by the National Center for Genetic improvement at Sidi Thabet, Tunis. In the north, where most of the large dairy farms are found, grass and silage are available all year round. Concentrated food supplements are entirely destined to cover the production requirements of cows. In central and southern regions of the country, intensive livestock farms predominate and concentrated feeds partly supplement basic feed rations (hay, straw, cacti, etc.) to cover cattle maintenance, growth and gestation requirements. The average forage to concentrate ratio was about $50 \%$. Only lactation records $>90 \mathrm{~d}$ in length and up to $506 \mathrm{~d}$ and coded as terminating normally were considered. Other reasons for rejection were duplicate records, calving age $<24$ months or lactation number $>7$ and no cow identification. Cows in this study with North American sires were $23 \%$ and cows with European sires were $15 \%$. The remaining cows did not have their pedigree reported. Most of the herds (78\%) were located in the Northern part of Tunisia known for its favorable environmental conditions and $22 \%$ of the herds were located in central regions with semi-arid environmental conditions. Ownership of herds was $27 \%$ private owners, $42 \%$ private enterprises, $25 \%$ state farms and $6 \%$ cooperatives. The data from 1998 to 2009 were analyzed by least squares techniques using the general linear models procedure of SAS, 2002 (1). First lactations were analyzed separately from second and later lactations by using the following model:

$$
\begin{gathered}
P_{i j \mathrm{j} l m n}=\mu+r_{i}+h_{i j}+c_{k}+f_{1}+o_{m}+ \\
+a_{n} b_{1} X_{i j k l m n}+b_{2} X_{i j k l m n}^{2}+e_{i j k l m n o}
\end{gathered}
$$

where $\mathrm{P}_{\mathrm{ijk} k \mathrm{mn}}$ is milk yield; $\mu$ is the underlying mean; $r_{\mathrm{i}}$ is region i $(1=$ North East, $2=$ North West, $3=$ Central East,
$4=$ Central West); $h_{i j}$ is effect of herd-year $\mathrm{j}$ in region $\mathrm{i} ; \mathrm{f}_{1}$ is effect of type of management ( $1=$ private owner, $2=$ private enterprise, $3=$ state farm herd, $4=$ cooperative); $\mathrm{o}_{\mathrm{m}}$ is effect of origin of cow sires $(1=$ North America, $2=$ Europe, $3=$ unknown); $a_{n}$ is effect of calving age group $n$ (3-mo intervals were formed from 21 to $>$ than 110 mo by respecting the biological order of lactations; $\mathrm{X}_{\mathrm{ijk} k m n}$ is actual days in milk for record $n ; b_{1}$ and $b_{2}$ are the linear and quadratic regression coefficients and $\mathrm{e}_{\mathrm{ijk}} \mathrm{mn}$ is the random residual.

Model (2) was used to analyze the data from second and later lactations:

$$
\begin{aligned}
& \mathrm{P}_{\mathrm{ijklmno}}=\mu+\mathrm{r}_{\mathrm{i}}+\mathrm{h}_{\mathrm{ij}}+\mathrm{c}_{\mathrm{k}}+11+ \\
& +\mathrm{f}_{\mathrm{m}}+\mathrm{o}_{\mathrm{n}}+\mathrm{a}_{\mathrm{o}} \mathrm{b}_{1} \mathrm{X}_{\mathrm{ijklmn}}+\mathrm{b}_{2} \mathrm{X}_{\mathrm{ij} \text { jlmn }}^{2}+\mathrm{e}_{\mathrm{ijklmnop}}
\end{aligned}
$$

where $r, h, c, f, o$ and a are as defined for Model(1) and 1 is effect of lactation number $(1=2-7)$.

\section{Results and Discussion}

\subsection{Sources of Variation}

Unadjusted means and standard deviations for milk yield and days in milk in first lactations were, respectively, $6004 \mathrm{~kg} \pm 1465 \mathrm{~kg}$ and $325 \mathrm{~d} \pm 92 \mathrm{~d}$. In second lactations and greater, milk yield and days in milk were $5990 \mathrm{~kg} \pm 1564 \mathrm{~kg}$ and $311 \mathrm{~d} \pm 91 \mathrm{~d}$, respectively. Important sources of variation of milk yield of Friesian cattle raised under South Mediterranean environmental conditions are reported in Table 1. Analyses of variance indicated that region, herd-year within region, month of calving, lactation number (for lactations greater than 1), calving age, country of origin and days in milk (linear and quadratic) were significant sources of variation for milk yield in the first and later lactations.

Table 1. F tests for significance of factors affecting first, second and later lactations in milk yield.

\begin{tabular}{lcccc}
\hline \multicolumn{1}{c}{ Source of variation } & \multicolumn{2}{c}{$1^{\text {st }}$ lactations } & \multicolumn{2}{c}{$>$ lactations } \\
\hline & $\mathrm{df}$ & $\mathrm{P}>\mathrm{F}$ & $\mathrm{df}$ & $\mathrm{P}>\mathrm{F}$ \\
\cline { 2 - 5 } Region & 3 & $* *$ & 3 & $* *$ \\
Herd-year within region & 1677 & $* *$ & 1930 & $* *$ \\
Type of ownership & 3 & $\mathrm{Ns}$ & 3 & $\mathrm{Ns}$ \\
Calving month & 11 & $* *$ & 11 & $* *$ \\
Lactation number & - & - & 5 & $* *$ \\
Country of origin & 3 & $* *$ & 3 & $* *$ \\
Calving age group & 4 & $* *$ & 26 & $* *$ \\
Days in milk & 1 & $* *$ & 1 & $* *$ \\
Linear & 1 & $* *$ & 1 & $* *$ \\
Quadratic & & 22456 & & 47536 \\
Residual & & 69 & & 63 \\
$\mathrm{R}^{2} \%$ & & & & \\
\hline
\end{tabular}

$* * \mathrm{P}<0.01$

Type of farm ownership was not significant in both 
analyzes. The distribution of records by lactation number, year of calving and month of calving are reported in Table 2 . Spring calving showed lower frequencies than the remaining months with a clear indication that calving is occurring all year round and no calving pattern is followed. There is a need, under these prevailing production systems to evaluate significantly different calving months or seasons and their implications in relation to herd performance, management issues and financial viability.

Table 2. Distributions of locations by lactation number, month and year of calving.

\begin{tabular}{cccccc}
\hline $\begin{array}{c}\text { Lactation } \\
\text { Number }\end{array}$ & $\begin{array}{c}\% \\
\text { Lactations }\end{array}$ & $\begin{array}{c}\text { Calving } \\
\text { month }\end{array}$ & $\begin{array}{c}\% \\
\text { Lactations }\end{array}$ & $\begin{array}{c}\text { Calving } \\
\text { year }\end{array}$ & $\begin{array}{c}\% \\
\text { lactations }\end{array}$ \\
\hline 1 & 33 & 1 & 10 & 1998 & 1 \\
2 & 25 & 2 & 8 & 1999 & 2 \\
3 & 18 & 3 & 7 & 2000 & 3 \\
4 & 11 & 4 & 6 & 2001 & 5 \\
5 & 7 & 5 & 6 & 2002 & 6 \\
6 & 4 & 6 & 7 & 2003 & 7 \\
7 & 2 & 7 & 9 & 2004 & 9 \\
& & 8 & 10 & 2005 & 12 \\
& & 9 & 9 & 2006 & 15 \\
& & 10 & 9 & 2007 & 18 \\
& & 11 & 9 & 2008 & 20 \\
\hline Total & \multirow{2}{*}{742001} & & 742001 & & 742001 \\
\hline
\end{tabular}

\subsection{Month of Calving}

The effect of month of calving on milk yield is given in table 3. These are the least squares solutions for month of calving in second and later lactations; the last month was restricted to 0 . The test of significance showed that there are two main seasons; the first season covers months from October until March and the second season covers months from May till September.

Table 3. Least squares solutions of calving month effect.

\begin{tabular}{cccc}
\hline $\begin{array}{c}\text { Calving } \\
\text { month }\end{array}$ & $\begin{array}{c}\% \\
\text { Lactations }\end{array}$ & $\begin{array}{c}\text { Least squares solutions } \\
(1998-2009)\end{array}$ & $\mathrm{Pr}>\mathrm{t}$ \\
\hline 1 & 10 & -49 & $\mathrm{NS}$ \\
2 & 8 & 9 & $\mathrm{NS}$ \\
3 & 7 & -28 & $\mathrm{NS}$ \\
4 & 6 & -85 & .03 \\
5 & 6 & -202 & $* *$ \\
6 & 7 & -227 & $* *$ \\
7 & 9 & -268 & $* *$ \\
8 & 10 & -269 & $* *$ \\
9 & 9 & -177 & $* *$ \\
10 & 9 & -75 & .02 \\
11 & 9 & -46 & $\mathrm{NS}$ \\
12 & 10 & 0 & $\mathrm{NS}$ \\
\hline
\end{tabular}

Cows calving during season one produced more milk than cows calving during season 2 . There was as much as $4 \%$ difference in yield from a cow calving in July-August than one calving in December. The effect of these seasonal variations in milk yield is depicted in figure 1.

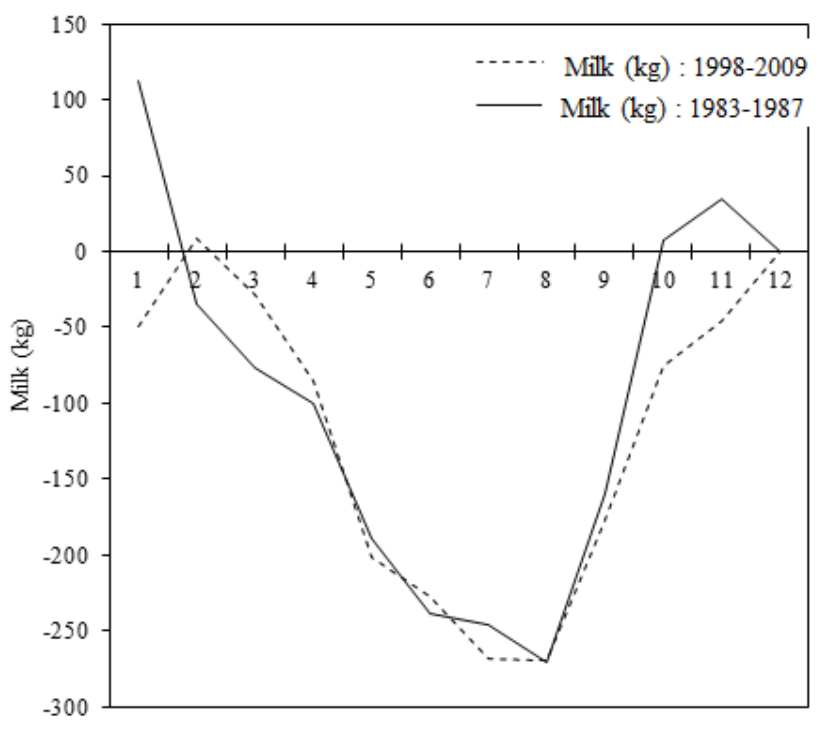

Figure 1. Effect of calving month on milk yield in both periods (1983-87, 1998-2009)

The same study conducted in the same region 15 years ago indicated the existence of three different calving seasons (September till January; February till May and June till August). Cows calving during September gave more milk (8\%) than cows calving in July-August (Djemali and Berger, 1992).

\subsection{Climate Change Evaluation}

Quantitative indicators of climate change effects could be assessed by models evaluating animal performances during time. This study used the effect of month of calving on milk yield of Friesian dairy cattle, raised under South Mediterranean conditions, as a measured indicator to climate change. The evaluation covers two distant periods (1983-1987) and (1998-2009). Least squares solutions of month of calving on milk yield obtained in this study were compared to those obtained in the first period (1983-1987) where 25,000 lactations from 156 Friesian herds were used (Table 4).

The comparison of least squares solutions from the 2 studies showed that in period 1 (1983-1987), cows calving in January yielded $384 \mathrm{~kg}$ more milk than cows calving in August. Differences in milk yield, compared to cows calving in August, were $278 \mathrm{~kg}, 306 \mathrm{~kg}$ and $271 \mathrm{~kg}$ more milk in favor of cows calving in October, November and December, respectively. The same trend was found in period 2 (1998-2009) but the amount of milk yield differences among cooler season and the hot season was less. 
Table 4. Comparison of least squares solutions of calving month during (1983-1987) and (1998-2009).

\begin{tabular}{ccc}
\hline C. month & LSS (1998-2009) & LSS (1983-1987) \\
\hline 1 & -49 & 113 \\
2 & 9 & -34 \\
3 & -28 & -76 \\
4 & -85 & -100 \\
5 & -202 & -189 \\
6 & -227 & -238 \\
7 & -268 & -246 \\
8 & -269 & -271 \\
9 & -177 & -160 \\
10 & -75 & 7 \\
11 & -46 & 35 \\
12 & 0 & 0 \\
\hline
\end{tabular}

C: Calving, LSS: Least squares solutions

Differences in milk yield observed between Januarys calving and Augusts calving were only $220 \mathrm{~kg}$. Differences were $192 \mathrm{~kg}, 221 \mathrm{~kg}$ and $268 \mathrm{~kg}$ in favor of cows calving in October, November and December, respectively compared to cows calving in august. The amount of these differences between the cool season and the hot season is lower compared to differences reported during period 1 . The general trend of these results might be translating a climate change effect toward warming up of the traditional known as cool season. The appealing aspect of this way of evaluating the effect of climate change is its association with the response of animals to their whole environment in a quantitative way. This is possible especially performance recording and modeling the biology is possible today. In addition, given the relatively long time frame (2050) before the projected full impact of climate change, as identified by the Intergovernmental Panel on Climate Change, modifications in animal genetic composition can be made to meet this challenge (Blackburn and Plante, 2014).

\section{Conclusions}

Assessment of climatic change could be achieved by appropriate modeling of animals' performances over time. The effect of month of calving on Friesian dairy cattle milk yield raised under South Mediterranean production environments allowed was evaluated during two periods
(1983-1987) and (1998-2009). The same trend measured by least squares solutions of calving month effect on milk yield was similar during the two periods, exception made of the amount of differences between months that was becoming smaller during the second period (1998-2009) identifying only two seasons (May-August) and (September-April). The previous study identified three different seasons (September-January), (February-May) and (June-August) for the period 1983-1987. This might be considered as a measured translation of climatic change.

\section{REFERENCES}

[1] Amies, S., 1981. Block Calving the dairy herd. Report by the Information Unit, Farm Management Services, Milk Marketing Board.

[2] Annis, D. J., Erb, R. E., Winters, W. R., 1959. Influence of month and season of calving on yields of milk and fat. Agricultural Experimental Station Report. State College of Washington. Published by Pulman, Washington.

[3] Blackburn, H., Plante, Y., 2014. North American animal breeding and production: meeting the needs of a changing landscape. Animal breeding and Genetics, 131:247-248.

[4] Djemali, S., Berger, J., 1992. Yield and reproduction Characteristics of Friesian Cattle under North African Conditions. J. Dairy Sci, 75: 3568-3575.

[5] FAO-Adapt. 2011. FAO's Framework programme on climate change adaptation. FAO 2011.

[6] Mostert, B.E., Theron, H.E., Kanfer, F.H.J., 2001. The effect of calving season and age at calving on production traits of South African dairy cattle. S. Afr. J. Anim. Sci. 31: 205-214.

[7] Poole, A. H., 1988. Responses to changes in the seasonality payments. Farm Management Services Information unit. Report $\mathrm{N}^{\circ}$ 61. Published by the Milk Marketing Board, September 1988.

[8] Raysildo, B. L., Duarte, F. A. M.C., Wilcox, J., 1980. Environmental and genetic effects on length of lactation in Brazilian tropical dairy breed. Rev. Brazil. Genet. III, 1, 31-40.

[9] SAS Institute Inc, 2002. 